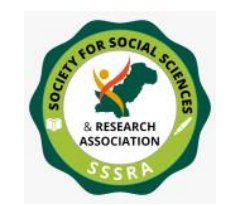

\title{
Book Review \\ Dying to Serve: Militarism, Affect, and the Politics of Sacrifice in the Pakistan Army
}

\author{
Sara Ahmad \\ PhD Scholar \\ Department of Political Science \\ Lahore College for Women University \\ Lahore - Pakistan \\ saraahmad5161@gmail.com
}

In every country, as an institution the military is responsible for protecting its physical borders and, at their request, helping the civilian government in a time of need. Pakistan's military is not only a defender of physical borders and ideological frontiers, it also directly or indirectly is involved in politics. It is a robust institution that safeguards the country from external and internal threats and is always ready to make sacrifices for the nation. Many books have been written on the subject of Pakistan's military from different perspectives, but Dr. Maria Rashid's book entitled "Dying to serve: Militarism, affect, and the politics of sacrifice in the Pakistan army" is a unique contribution that deals with 'militarism' and exposes the mechanisms through which it operates in Pakistan. This book has been critically written under diverse and well-arranged themes. Previous studies discuss the high ranking military officers, but omit the martyred soldiers and their poor families coming from socio-economically backward areas. Also highlighted throughout the book is the feminine role of members of the soldiers' families.

This book was published in April 2020 and consists of nine chapters and is an ethnographic study based on participant observation and fieldwork, sharing historical and contextual information. Five villages in the district of Chakwal, located in the province of Punjab, Pakistan, were selected for fieldwork. Punjab is a dominant province (especially the villages in Punjab) from where a large number of soldiers were recruited during the British colonial period and since the inception of Pakistan in 1947. More than one hundred interviews were conducted with military officers, junior commissioned officers, non-commissioned officers, family members of martyred soldiers, as well as retired and serving soldiers, civilians, and people who were significant to the exploration of this area of study. The title of the 


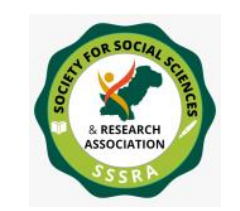

Pak. Journal of Int'L Affairs, Vol 3, Issue 2 (2020)

Dying to Serve Militarism, Affect, and the...

book has justified bringing 'militarism' and its effect on soldiers, their families, and the 'politics of sacrifice' in the Pakistan army into the limelight.

This book begins with the event of Youm-e-Difah, a national military commemorative ceremony commenced in 2015 at Yadgar-e-Shuhada (Martyrs' Memorial) which was attended by the author, and she expresses her concerns when observing the emotions of pride and grief of the martyred families to the sacrifice of their sons for their country. She examines the arrangements of national military commemorations Youm-e-Shuhada and Youm-e-Difah that were organized for the soldiers martyred in the wars and counter-insurgencies. Through these commemorations, the military built up the morale of the troops and used religion as a national ideology in these ceremonies. The term 'technology of rules' is used to show martyrdom as a tool used to establish the domination of the military in the country. The author deconstructs the narrative of Shahadat that emotionally appeals to the general masses and discusses the feminine perspective in this regard, which has been overlooked in other military studies in Pakistan.

The author explains the phenomenon of 'militarism' in the broader context as:

“... existence of massive armies, paramilitaries, and military contractors; production and accumulation of arms; growing state ability for surveillance; use of militarized imagery in popular culture; militarization of university and research agendas; making of national histories to glorify military action; and belief that military efficiency is integral to state survival and security".

Militarism can be seen in our culture, literature, commemoration of national days, involvement in national disasters, maintaining political upheaval and law and order, public welfare, assisting in the election process, etc.

This book exposes the recruitment history, policies and rigorous military training procedures that transform the heart, mind and body of an ordinary person so that he becomes different as a soldier, which the author calls the "manufacturing of the soldier'. The author highlights the political, social, economic development and importance of the Chakwal District (Land of Valient) as a major recruiting area of the military during and post-colonial time. 
Maria Rashid's study is based on interviews and fieldwork, which is why she shares the experiences, the life stories of soldiers during their training period, and narrates the funeral rituals of shuhada, buried with military honours and a dignity that is different from the funeral of a civilian. Furthermore, she discusses the compensation packages for the families of martyrs and disabled military personnel in the War on Terror or during military operations in combat areas. Disputes that arise regarding the compensation packages between family members are also highlighted, and how they are reconciled.

She also talks about rehabilitation facilities for soldiers who are disabled during operations in the combat areas. Youm-e-Difah and Youm-e-Shuhada ceremonies pay tribute to their heroism, but nobody can imagine how hard a life they face with their disability. The author uses the term 'Pro Patria Mori' (to die for one's country) to explain the religious influence and the use of religion throughout the history of Pakistan in chronological order from the inception of Pakistan to the Soviet-Afghan war and the events of 9/11. Religious and nationalist elements motivate the soldiers to sacrifice their lives for their country. As the author writes: "Dying in military service has become synonymous with dying for Islam". 